\title{
Determinants of Credit Card Delinquency and Bankruptcy: Macroeconomic Factors
}

\author{
Sumit Agarwal and Chunlin Liu*
}

\begin{abstract}
In this paper, we examine how county unemployment rates affect consumers' delinquency and bankruptcy behavior by focusing on the credit card market. In particular, after controlling for credit supply and shocks like divorce and health coverage we investigate whether consumer propensity for delinquency and bankruptcy changes with respect to the macroeconomic fluctuations across counties. Our results show that county unemployment rates significantly influence delinquency. (JEL G30, G33)
\end{abstract}

\section{Introduction}

A number of studies have show that macroeconomic factors, specifically unemployment, are a significant determinant in a household's delinquency and bankruptcy decision (Hendershott and Schultz 1993; Repetto 1998; Deng, Quigley, and Van Order 2000; Livshits, MacGee, and Tertilt 2001; Agarwal, Chomsisengphet, and Elul 2002). Yet others have failed to show unemployment is a significant determinant of bankruptcy (Elul and Subramanian 2002; Fay, Hurst, and White 2002). Hence, as pointed out in a study by the Congressional Budget Office (CBO 2000), "empirical studies do not consistently find that macroeconomic factors significantly affect the filing rate (p. 11)," but surveys of bankruptcy filers have consistently shown that unemployment is a significant determinant in the decision to file for bankruptcy. Sullivan, Warren, and Westbrook (2000) analyze a survey of 1991 bankruptcy filings and find that 67.5 percent of filers claim loss of job as the main cause of their bankruptcy filing. Repetto (1998) shows that among a sample of 1996 PSID bankruptcy filers 20 percent name loss of job as their main cause for household bankruptcy filing decision.

This has led researchers to argue that the past seven years (1995-2001) have been an era of high economic growth and very low national and thus state unemployment, yet there has been a substantial rise in credit card delinquency and personal bankruptcy filings. Given such trends, macroeconomic factors may not be the primary determinants of delinquency and bankruptcy

\footnotetext{
Sumit Agarwal, Sumit_Agarwal@fleet.com, and Chunlin Liu, Chunlin_Liu@fleet.com, FleetBoston Financial, MailStop: RI DE 03306C, 111 Westminster Street, Providence, RI 02903. The authors would like to thank Jim Papadonis and Joanne Maselli for their support of this research project; Souphala Chomsisengphet, Ronel Elul, Larry Mielnicki, and especially Nick Souleles for their valuable comments and suggestions; and Tim Murphy for his help with excellent research assistance. The views expressed are those of the authors and do not necessarily represent those of FleetBoston Financial.
} 
during this recent period. Gross and Souleles (2002) attribute the rise in consumer delinquency and bankruptcy during this period to risk-composition effects and a decrease in the cost of bankruptcy, including legal and social cost.

In view of the above arguments, this paper will try to understand the relationship between macroeconomic factors, specifically unemployment and consumer delinquency as well as bankruptcy. The underlying hypothesis of this paper is that cardholders, as a result of negative macro shocks to the economy, find themselves unemployed. In turn, they increase their credit card indebtedness to compensate for the lost source of income in the hope of repaying the debt as soon as they are employed. This leads them to become delinquent on their monthly payments either in the same month or months soon thereafter. If they do not find a job in the next few months, they declare bankruptcy or default.

Several other papers have studied the determinants of delinquency and bankruptcy. Grieb, Hegji, and Jones (hereafter GHJ 2001), look at time series data to study consumer behavior, macroeconomic factors, and credit card default. They use aggregated quarterly data over 19 years and find that unemployment leads to a rise in credit card default rates. ${ }^{1}$ Gross and Souleles (2002), on the other hand, using account level data conduct an empirical analysis of the demand for unsecured (credit card) credit and its impact on consumer delinquency and bankruptcy. They estimate a duration model to assess the relative importance of different variables in predicting default. In particular, they estimate the impact of (i) internal and external score ("risk-effects") on default; (ii) age (seasoning) on default; (iii) changes in the costs of default, and (iv) social and macro shock effects ${ }^{2}$ on default. They conclude that risk, age, macro, and social factors are statistically significant in determining default. However, once they control for all of the above effects as well as state dummies, then the macroeconomic effect (state unemployment) is statistically insignificant. It is possible that their sample period does not have enough variation in unemployment.

Fay, Hurst, and White (2002) conduct an empirical analysis of the demand for secured and partially secured credit and its impact on consumer delinquency and bankruptcy. They estimate a logit model using a new Panel Study of Income Dynamics (PSID) data set on bankruptcy filings. They test whether households are more likely to file for bankruptcy when their financial benefit from filing rises. They also control for some of the factors mentioned above (except risk and seasoning), but they have a richer set to demographic controls. They conclude that an increase of $\$ 1,000$ in a household's financial benefit from bankruptcy filing is associated with an increase of 2.1 percent in the probability of bankruptcy. Once they control for all the legal, social, and demographic variables, then the macroeconomic effects (county unemployment) are statistically insignificant. However, the PSID contains only a couple of hundred observations of bankruptcy, and so their sample might not be large enough to identify the effect of local differences in unemployment.

Deng, Quigley, and Van Order (2000), under the option theory framework, predict whether a call or put option is "in the money" for mortgage prepayment and default. They present a unified model of the competing risks and show that macroeconomic factors (state unemployment rate) are statistically significant. In another study, Domowitz and Sartain (1999) estimate a bankruptcy choice model and attribute credit card indebtedness as the largest single contributor to the

\footnotetext{
${ }^{1} \mathrm{GHJ}$ also test the notion of "selective default," i.e. individual borrowers rationally choose credit card default over default on other types of loans when they find themselves having trouble making payments. Since they were unable to investigate the behavior of individual consumers our results confirm their initial findings using account level data.

${ }^{2}$ Responses to the PSID survey of participants that filed bankruptcy between 1984-95 reveal that 12.2 percent filed due to loss of job, 14.3 percent filed due to divorce, 41.3 percent filed due to credit mismanagement, 16.4 percent filed due to health related cost not covered by insurance, and 15.9 percent filed due to lawsuit related costs. These statistics indicate that shock effects are a significant contributor to bankruptcy.
} 
bankruptcy filing decision of a household. In fact, they predict that an increase in credit card indebtedness to the level of an average bankruptcy filer will cause a minimum of a 498 percent rise in the probability of bankruptcy filing. One possible explanation for such strong results could be due to endogeneity of credit card debt to bankruptcy filings. However, they do not find unemployment to be a significant factor in a bankruptcy choice model. One possible explanation is that their sample also contains few observations of default since they used the Survey of Consumer Finance (SCF) data.

The objective of our paper is to look at the effect of unemployment on consumer delinquency and bankruptcy using credit card data from 1995 to 2001 for around 700 thousand customers. Two big advantages that our study has over the previous studies are that (i) we have a panel data set as opposed to most previous studies, which either have a cross section or a time series estimation (except Gross and Souleles 2002), and (ii) we have data that covers both the expansion and subsequent recession so we can capture the variation in the unemployment rates over time and not only across counties. The results are robust and provide conclusive evidence that county unemployment is critical in determining delinquency and bankruptcy.

The structure of the rest of the paper is as follows. The next section describes the model specification and data. The third section discusses the empirical findings, and the fourth offers concluding remarks.

\section{Data and Model Specification}

\section{Data}

This study uses a proprietary database primarily from a large financial institution that issues credit cards nationally. Several aspects of this data set are both unique and appealing for studying the impact of unemployment on delinquency and personal bankruptcy. This data set includes two million individual accounts that originated between January 1975 and December 1998. However, we only have monthly credit card usage behavior for all accounts from January 1994 to December 2001. For accounts that originated before January 1994, the data set includes one observation that indicates the date of origination, the bureau credit score at origination, the line of credit, and other account-specific information at origination. We also have point-in-time information on the customers if they left the data set any time before January $1994 .{ }^{3}$ Hence, it can be argued that accounts that originated before January 1994 are likely to have "survival bias," since we do not have credit card usage behavior of accounts that left the data set prior to January $1994{ }^{4}$ So we exclude all accounts that originated before January 1994.

For all the accounts that originated before or after January 1994, the data set has all the variables that were collected at the time of account origination. We also have access to all the performance data since January 1994. Hence, if an account originated in January 1994 and the account is still in good standing, then we would have performance data for the eight-year period. The data include quarterly bureau credit score updates, internal monthly behavior score updates, borrower's self-reported personal income at origination, credit limit, default indicators, and other

\footnotetext{
${ }^{3}$ There are several possible reasons for them to leave the data set: (i) they could have defaulted on the account; (ii) declared bankruptcy; or (iii) closed the account in good standing. It is important that we distinguish between accounts that default and declare bankruptcy. Default constitutes an account that is 180 days past due on their payments but a customer who is in good standing can choose to declare bankruptcy. Hence, default is not a pre-requisite for bankruptcy or viseversa.

${ }^{4}$ Carpenter and Lynch (1999), discuss the issue of survival bias in the context of mutual funds. They conduct simulations and conclude that when the survival depends on performance over several periods then survivorship bias induces spurious reversals, despite the cross-sectional heteroskedasticity in performance.
} 
variables that characterize an account standing with the creditor. All these variables control for the "risk composition effect" as described in Gross and Souleles (2002).

Our data also include county unemployment rate, ${ }^{5}$ percentage of people without medical coverage, divorce rate, ${ }^{6}$ and other demographic characteristics for each state. For the purpose of this study, we follow an account originated after January 1995 with performance data for the next three years. ${ }^{7}$ For example, an account that originated in January 1995 was tracked until December 1997. If the account was 90 days past due at any time within the three years a delinquency flag was created for that account. If the account was bankrupt at any time, a formal bankruptcy flag was created. Since a cardholder can declare bankruptcy before the account is 90 days delinquent (approximately 20-30 percent), the model captures individuals that are either delinquent or have declared bankruptcy. Hence, for the rest of the paper, whenever we refer to an account's being 90 days delinquent, we do include accounts that also have declared bankruptcy prior to being delinquent. Furthermore, accounts with a flag indicating lost, stolen, never active, or closed due to fraud/death status were excluded from the analysis.

The final data set included more than 700,000 accounts that originated after January 1995 or 21 million observations. Since it was not feasible to estimate the various model specifications using a proportional hazard model on the entire data set, we worked on a random subsample of 203,103 accounts.

\section{Methodology}

We estimate a duration model for delinquency. Let $D_{i, t}$ indicate whether an account $i$ becomes delinquent in month $t$. Using the proportional hazard model, we estimate the conditional probability of delinquency at time $t$, assuming the consumer is current from inception up to time $t$ 1. For instance, the account could become three cycles delinquent in month 18 ; then $D_{i, t}=0$ for the first 17 months, and $D_{i, 18}=1$, and the rest of the observations will drop out of the sample. ${ }^{8}$ The main specification would be as follows:

$$
D_{i, t}=\beta_{1} \text { Time }_{t}+\beta_{2} \text { State }_{\text {County }}+\beta_{3} X_{i, t}+\beta_{4} S_{i, t}+\beta_{4} L_{i, t}+\beta_{5} U_{i, t}+\varepsilon_{i, t}
$$

Time $_{t}$ represents calendar month dummies. State/County ${ }_{i}$ represents state or county dummies corresponding to the 50 states or more than 3,000 counties. $X_{i, t}$ represents account-specific measures of risk. They include account balance, credit limit, interest rate, internal and external scores, and others. $S_{i, t}$ represents state-specific "shock" variables like divorce rates, bankruptcy filings, and health coverage. $L_{i, t}$ represents state-specific legal variables, including homestead, property, and garnishment exemption levels. $\mathrm{U}_{i, t}$ represents county-specific unemployment rates. We estimate several specifications of the above general model.

\footnotetext{
${ }^{5}$ County unemployment rates are only available from January 1995 to December 2001. Hence, we cannot include credit-card usage prior to January 1995.

${ }^{6}$ It is worth noting that four states (California, Colorado, Indiana, and Louisiana) do not report divorce rate information whereas two other states (Nevada and Texas) do not have a complete time series for the period covered in our study (www.cdc.gov/nchs/nvss.htm).

${ }^{7}$ We conducted a similar analysis with a shorter performance window of two years, and the results are qualitatively the same.

${ }^{8}$ This is the most common form of incomplete data, also defined as right censored. Accordingly, all customers start at time $t=0$, and a customer could drop out of the sample because he closes the account in good standing or even stay current till the end of three years without being delinquent or declaring bankruptcy. As discussed earlier, we do not consider leftcensoring in our analysis (accounts that have already been delinquent or declared bankruptcy even before the observation of time begins).
} 
First we use a semiparametric model to estimate the baseline survival function to understand the average delinquency rate over time and across states or counties. The semiparametric modeling allows for no assumption about the parametric distribution of the survival times, making the method considerably more robust. ${ }^{9}$

Having estimated the baseline survival function, next we would like to estimate the effect of both the home and property exemptions that vary across states but not over time. Since the legal variables do not vary over state-time within the sample period, we have estimated the model without state or county dummies, allowing us to capture the effect of the legal variables. Otherwise the state or county dummy would wipe out the effect of the legal variables. However, since the objective of this study is not to study the effect of legal variables on delinquency, and including them in the estimation prohibits us from controlling for state or county dummies, we drop the legal variable for the rest of the model specifications.

Next we are also interested in estimating the effect of divorce rates on delinquency. However, as discussed in the data section, four of the states do not publish divorce statistics, and so we estimated one model specification that included the divorce rate variable and excluded the four states (California, Colorado, Indiana, and Louisiana) and another specification that excluded divorce rate variable and included these states. The results show that divorce rate is statistically significant but does not affect the overall results once it is excluded. However, since the objective of this study is not to study the effect of divorce rate on delinquency, and including it in the estimation prohibits us from including all 50 states, we drop the divorce rate variable for the rest of the model specifications.

The next few specifications control for different lag structures for the risk, social, and macro variables. Recall that $D_{i, t}$ represents accounts that are three months delinquent, so we lag the macro variable by three months. We also lag the risk and social variables by three months to study the impact at the point the account was in good standing. It is important to lag the risk variables by three months because otherwise the risk variables will capture all the effect on delinquency and bankruptcy (Gross and Souleles 2002). Next, we lag the risk variables by six months and leave the lag on the social and macro variables at three months. We also lag the macro variable by six months and lag the risk and social variables by three months. This specification assumes that the consumer has sufficient liquidity to pay debt for the next three months on his credit cards, auto, and mortgage. We also calculate a variable that measures the change in unemployment rates between the past six and three months. This specification assumes that it is not the unemployment rate that is an important determinant of delinquency and bankruptcy but the change in the unemployment rate. Other specifications include (i) a quadratic term for the risk variables (internal score, internal score ${ }^{2}$, external score, external score ${ }^{2}$, balance, balance ${ }^{2}$ ); and (ii) county dummies instead of state dummies.

\section{Empirical Findings}

Although the objective of the study is to estimate the impact of unemployment on credit card delinquency, we first estimate the baseline survival functions by state, that is, the cumulative

\footnotetext{
${ }^{9}$ However, since we only have accounts with a maximum age of 32 months we do not see the same inverted-U shaped curve implying that the probability of delinquency rising in the first 24-30 months and then falling and stabilizing over time as discussed in Gross and Souleles (2002). However, we conducted similar analysis using accounts of varying ages and terminating anywhere from three to eight years and our results are similar to those in Gross and Souleles (2002). For the purpose of this study we did not include accounts of varying ages since they could potentially cause a survival bias, as discussed above.
} 
likelihood of a loan's "surviving" (i.e., not being delinquent) over time. ${ }^{10}$ Figure 1 presents survival functions for three states and an overall survival function for all states. These estimated survival functions indicate that-under the market conditions faced by the borrower in our sample - nearly 4.5 percent were delinquent in Florida as compared to 2.5 percent in Massachusetts, and 3.5 percent overall, over a 32-month period. ${ }^{11}$ These findings underscore the need to properly control for these factors, which enter the equation in nonlinear fashion, in comparing delinquency propensities over time. The coefficients were based on the mean values for all the independent variables over the analysis months.

Figure 1. Survival Function for Selected States

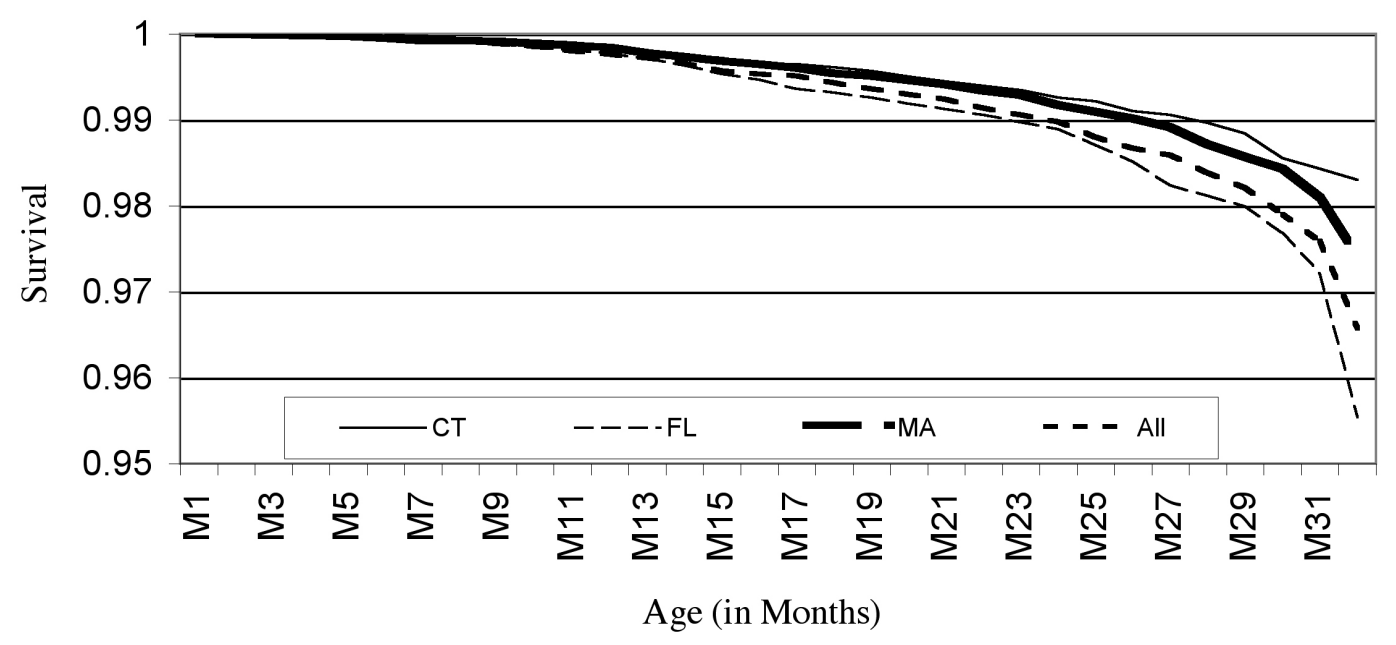

Proportional Hazard Results

Table 1 presents results for the various specifications discussed in the previous section. There are 17 specifications in all where $X$ captures customer-specific risk factors like internal and external scores, account balance, and line amount. $S$ captures state-specific factors like average income and people without health coverage. $U$ captures county unemployment rates. Certain specifications also include APR, divorce rates, and state bankruptcy exemption levels. All these specifications also control for time and state/county dummies, which are each jointly significant.

Table 1 only reports the coefficients of unemployment; the appendix shows the other estimates for the first specification. ${ }^{12}$ The first specification (row 1) assumes a lag of three months for all variables $(X, S$, and $U)$. Both internal and external scores are highly significant and negative. Line amount is also significant and negative. This indicates that credit supply is negatively related to delinquency.$^{13}$ However, account balance is positive and significant. All these are consistent with prior research (Gross and Souleles 2002). Moreover, they are significant in all of the 17 specifications.

${ }^{10}$ In the partial likelihood framework, the survival function can be estimated from the semiparametric estimator $\mathrm{S}\left(\tau, \mathrm{x}_{\mathrm{it}}\right)=\left(\mathrm{S}_{0}(\tau)\right)^{\exp \left(\mathrm{x}_{\mathrm{it}}{ }^{\beta}\right)}$, where $\mathrm{S}_{0}(\tau)$ represents the baseline survival function. For further discussion, see Bennett, Peach, and Peristiani (2001).

${ }^{11}$ These states represent the minmum, maximum, and median survival rates over time.

${ }^{12}$ Results for the rest of the specifications are available from the authors upon request.

${ }^{13}$ See Gross and Souleles (2002) for a discussion for this result. 
State average income is statistically significant and negative; this would imply that customers in states with higher income have a lower probability of defaulting. States that have a higher number of individuals with no medical coverage are also likely to have a higher rate of delinquency. This is intuitive and consistent with prior research (Domowitz and Sartain 1999; Gross and Souleles 2002). All of the above results are consistent for all of the 17 specifications.

Hence, we will only concentrate on county unemployment and its impact on delinquency. The first specification shows that unemployment is significant at the 5 percent level. The next specification (row 2) lags the $X$ variables by six months, and unemployment is significant at the 5 percent level, though less so.

TABLE 1. RESPONSE OF CREDIT CARD DELINQUENCY AND BANKRUPTCY TO UNEMPLOYMENT

\begin{tabular}{|c|c|c|c|c|c|c|c|c|c|}
\hline \multirow[t]{2}{*}{$\begin{array}{c}\text { Row } \\
\#\end{array}$} & \multirow[t]{2}{*}{$\begin{array}{l}\text { Dependent } \\
\text { Variable }\end{array}$} & \multicolumn{2}{|c|}{ Unemployment } & \multicolumn{2}{|c|}{$\begin{array}{c}\text { Change } \\
\text { Unemployment }\end{array}$} & \multicolumn{2}{|c|}{$\begin{array}{l}\text { Unemployment - } \\
\text { Square }\end{array}$} & \multirow[t]{2}{*}{$\begin{array}{c}\log \\
\text { Likelihood }\end{array}$} & \multirow[t]{2}{*}{$\begin{array}{l}\text { Pseudo } \\
\mathrm{R}^{2}\end{array}$} \\
\hline & & Coeff Value & T-stat C & Coeff Value & T-stat & Coeff Value & T-stat & & \\
\hline 1 & $\begin{array}{l}\mathrm{X}_{\mathrm{t}-3,}, \mathrm{~S}_{\mathrm{t}-3,}, \mathrm{U}_{\mathrm{t}-3,} \text {, Fixed Effects } \\
\text { (State, Year/Month) }\end{array}$ & 0.002133 & 5.32 & & & & & 18,745 & 0.293 \\
\hline 2 & $\begin{array}{l}\mathrm{X}_{\mathrm{t}-6}, \mathrm{~S}_{\mathrm{t}-3,} \mathrm{U}_{\mathrm{t}-3,} \text { Fixed Effects } \\
\text { (State, Year/Month) }\end{array}$ & 0.01527 & 3.46 & & & & & 18,652 & 0.283 \\
\hline 3 & $\begin{array}{l}\mathrm{X}_{\mathrm{t}-3,} \mathrm{~S}_{\mathrm{t}-3}, \mathrm{U}_{\mathrm{t}-3,} \text { Fixed Effects } \\
\text { (County, Year/Month) }\end{array}$ & 0.007 & 0.56 & & & & & 53,428 & 0.321 \\
\hline 4 & $\begin{array}{l}\mathrm{X}_{\mathrm{t}-6,} \mathrm{~S}_{\mathrm{t}-3,} \mathrm{U}_{\mathrm{t}-3,} \text { Fixed Effects } \\
\text { (County, Year/Month) }\end{array}$ & 0.0283 & 2.32 & & & & & 50,616 & 0.301 \\
\hline 5 & $\begin{array}{l}\mathrm{X}_{\mathrm{t}-3,}, \mathrm{~S}_{\mathrm{t}-3}, \mathrm{U}_{\mathrm{t}-6,} \text { Fixed Effects } \\
\text { (State, Year/Month) }\end{array}$ & 0.00355 & 2.47 & & & & & 16,575 & 0.301 \\
\hline 6 & $\begin{array}{l}\mathrm{X}_{\mathrm{t}-\mathrm{6},} \mathrm{S}_{\mathrm{t}-3,} \mathrm{U}_{\mathrm{t}-3,} \text { Fixed Effects } \\
\text { (State, Year/Month), APR } \mathrm{t}_{\mathrm{t}-3}\end{array}$ & 0.05692 & 10.22 & & & & & 23,652 & 0.309 \\
\hline 7 & $\begin{array}{l}\mathrm{X}_{\mathrm{t}-\mathrm{6},} \mathrm{S}_{\mathrm{t}-3,} \mathrm{U}_{\mathrm{t}-3,} \text {, Fixed Effects } \\
\text { (State, Year/Month), Divorce } \mathrm{t-3}\end{array}$ & 0.01495 & 3.14 & & & & & 23,356 & 0.299 \\
\hline 8 & $\begin{array}{l}\mathrm{X}_{\mathrm{t}-6,} \mathrm{~S}_{\mathrm{t}-3}, \mathrm{U}_{\mathrm{t}-3,} \text { Fixed Effects } \\
\text { (Year/Month), Exemptions } \mathrm{t}-3\end{array}$ & 0.01251 & 2.98 & & & & & 24,322 & 0.293 \\
\hline 9 & $\begin{array}{l}\mathrm{X}_{\mathrm{t}-6,}, \mathrm{~S}_{\mathrm{t}-3}, \mathrm{U}_{\mathrm{t}-3,}, \mathrm{dU}_{(\mathrm{t}-3)-(\mathrm{t}-\mathrm{-})}, \text { Fixed } \\
\text { Effects (State, Year/Month) }\end{array}$ & 0.015 & 3.28 & 0.00173 & 0.22 & & & 15,266 & 0.284 \\
\hline 10 & $\begin{array}{l}\mathrm{X}_{\mathrm{t}-\mathrm{6},} \mathrm{S}_{\mathrm{t}-\mathrm{3},} \mathrm{U}_{\mathrm{t}-3,}, \mathrm{dU}_{(\mathrm{t})-(\mathrm{t}-3),} \text {, Fixed } \\
\text { Effects (State, Year/Month) }\end{array}$ & 0.01876 & 4.16 & 0.03567 & 3.63 & & & 18,636 & 0.288 \\
\hline 11 & $\begin{array}{l}\mathrm{X}_{\mathrm{t}-3,}, \mathrm{~S}_{\mathrm{t}-3,} \mathrm{U}_{\mathrm{t}-3,}, \mathrm{dU}_{(\mathrm{t}-\mathrm{-})-(\mathrm{t}-\mathrm{9})}, \text { Fixed } \\
\text { Effects (State, Year/Month) }\end{array}$ & 0.01824 & 3.49 & -0.00505 & -0.7 & & & 15,393 & 0.312 \\
\hline 12 & $\begin{array}{l}\mathrm{X}_{\mathrm{t}-3,}, \mathrm{~S}_{\mathrm{t}-3,} \mathrm{U}_{\mathrm{t}-\mathrm{6}}, \mathrm{dU}_{(\mathrm{t}-3)-(\mathrm{t}-\mathrm{-})} \text {, Fixed } \\
\text { Effects (State, Year/Month) }\end{array}$ & 0.01781 & 3.46 & 0.00321 & 0.35 & & & 18,309 & 0.319 \\
\hline 13 & $\begin{array}{l}\mathrm{X}_{\mathrm{t}-\mathrm{6},} \mathrm{S}_{\mathrm{t}-\mathrm{3},} \mathrm{U}_{\mathrm{t}-\mathrm{6}}, \mathrm{dU} \mathrm{U}_{(\mathrm{t}-\mathrm{-3})(\mathrm{t}-\mathrm{-})}, \text { Fixed } \\
\text { Effects (State, Year/Month) }\end{array}$ & 0.01798 & 3.51 & 0.00276 & 0.31 & & & 18,320 & 0.318 \\
\hline 14 & $\begin{array}{l}\mathrm{X}_{\mathrm{t}-3,}, \mathrm{~S}_{\mathrm{t}-3,} \mathrm{U}_{\mathrm{t}-\mathrm{9}}, \mathrm{dU} \mathrm{U}_{(\mathrm{t}-\mathrm{-})-(\mathrm{t}-\mathrm{9})}, \text { Fixed } \\
\text { Effects (State, Year/Month) }\end{array}$ & 0.01792 & 3.42 & 0.00168 & 0.23 & & & 17,304 & 0.302 \\
\hline 15 & $\begin{array}{l}\mathrm{X}_{\mathrm{t}-\mathrm{9},} \mathrm{S}_{\mathrm{t}-\mathrm{9}} \mathrm{U}_{\mathrm{t}-\mathrm{9}}, \mathrm{dU}_{(\mathrm{t}-\mathrm{-3})(\mathrm{t}-\mathrm{9})} \text {, Fixed } \\
\text { Effects (State, Year/Month) }\end{array}$ & 0.01923 & 3.70 & 0.00136 & 0.18 & & & 15,039 & 0.323 \\
\hline 16 & $\begin{array}{l}\mathrm{X}_{\mathrm{t}-\mathrm{-},} \mathrm{X}_{\mathrm{t}-\mathrm{-}}^{2}, \mathrm{~S}_{\mathrm{t}-3,} \mathrm{U}_{\mathrm{t}-3,}, \mathrm{dU}_{(\mathrm{t}-3)-(\mathrm{t}-6)} \\
\text { Fixed Effects (State, } \\
\text { Year/Month) }\end{array}$ & 0.01891 & 4.18 & 0.0323 & 3.21 & & & 15,993 & 0.313 \\
\hline 17 & $\begin{array}{l}\mathrm{X}_{\mathrm{t}-6,} \mathrm{X}_{\mathrm{t}-6}^{2}, \mathrm{~S}_{\mathrm{t}-3}, \mathrm{~S}_{\mathrm{t}-3}{ }^{2}, \mathrm{U}_{\mathrm{t}-3,} \mathrm{U}_{\mathrm{t}-3}{ }^{2}, \\
\text { Fixed Effects (State, } \\
\text { Year/Month) }\end{array}$ & 0.01451 & 1.08 & & & 0.000362 & 0.45 & 14,203 & 0.285 \\
\hline
\end{tabular}

Notes: The table shows the results for the proportional hazard model of delinquency using monthly credit card panel data from January 1995 to December 2001. The independent variables control for calendar time, account seasoning, state fixed effects, account-specific risk characteristics, and other shock effects like state divorce rates, state health care coverage, and county unemployment rates. 
We also want to validate these results by controlling for county fixed effects as opposed to state fixed effects. We estimate two specifications (rows 3 and 4) in this regard, one where we lag the $X$ variables by three months and the other where we lag the $X$ variables by six months. It is not surprising that the first specification (row 3 ) shows unemployment to be insignificant, whereas the second specification (row 4) shows unemployment to be highly significant in determining delinquency and bankruptcy. This confirms the endogeneity of unemployment in the risk variables.

The next specification (row 5) is estimated with a specific assumption about the unemployment nature - we assume that an individual is unemployed three months prior to his first delinquency month. We find that unemployment is still highly significant. As discussed in the previous section, we conducted the next three specifications (rows 6 through 8) to validate our results by controlling for APR, divorce rate, and bankruptcy exemption levels without state dummies (Agarwal, Liu, and Mielnicki 2002). While APR as well as exemptions are highly significant and positive, divorce rate is marginally significant, but the most critical variable (unemployment) is significant in all these specifications.

Specifications 9 through 16 (rows 9 through 16) include a change in unemployment variable in addition to the variables discussed above $(X, S$, and $U$ ). The change in unemployment is usually insignificant, though it is significant in rows 10 and 16. All these specifications also show that the level of unemployment is statistically significant. Hence, the level of unemployment appears to be more important than the change in unemployment. Specification 17 (row 17) includes an additional variable to test whether unemployment has any nonlinear properties. However, the coefficient for the unemployment square term is statistically insignificant.

Finally, we estimate the marginal impact of a percentage-point change in unemployment on delinquency. The results show that delinquency will increase by around 1.9 percentage points to 2.8 percentage points depending on the specification. Specifically, for model specification in Row 1 , with a three-month lag between an individual's being unemployed and subsequently being 90 days delinquent, there is a 1.9 percentage point increase in the delinquency for every one percentage point rise in unemployment (Row 1). In Row 5, with a six-month lag between an individual's being unemployed and subsequently being 90 days delinquent, there is a 2.8 percentage point increase in the delinquency for every one percentage point rise in unemployment (Row 5). We believe that the rise in delinquency is higher in the latter case because of the fact that individuals who anticipate a new job in the near future while maintaining a good credit standing with their creditors (mortgage, credit cards, and/or auto) are more likely to declare bankruptcy once they do not find the job and in the meanwhile to have depleted their liquid reserves. These results also provide support to the "selective default behavior" documented by GHJ. One would expect that consumers that are unemployed 90 days prior to missing their first payment (or 180 days delinquent) may have depleted more of their liquid reserves and be forced to default not only on their credit card debt but all other debt as well. However, our results suggest that consumers who lost their job days prior to missing their first payment (or 90 days delinquent) might exhibit "selective default behavior" by acting strategically and becoming delinquent on their credit card payments to conserve the liquid reserves for other debt payments. 


\section{Conclusion}

As pointed out by the Congressional Budget Office report, "empirical studies do not consistently find that macroeconomic factors significantly affect the filing rate" (p. 11). This was a comprehensive study that looked at the effect of unemployment on consumer delinquency and bankruptcy using credit card data from 1995 to 2001 for around 700 thousand customers. The results are robust and provide conclusive evidence that unemployment is critical in determining delinquency. These results partially support the earlier time series finding of GHJ, where we also find that higher unemployment rates lead to a rise in delinquency rates. However, though GHJ finds that supply of consumer credit is positively related to delinquency, our results indicate credit limit (a proxy for credit supply) is negatively related to delinquency (see appendix). One possible explanation is the nature of data used for the two studies. While they used aggregated quarterly data over a 19-year period, this study uses monthly individual account level data from 1995 to 2001 with credit supply, interest rate, and other customer financial information.

\section{References}

Agarwal, S., S. Chomsisengphet, and R. Elul. 2002. "Personal Bankruptcy Exemptions and Mortgage Default.” Mimeographed. Brown University.

Agarwal, S., C. Liu, and L. Mielnicki. 2003. "Exemption Laws and Consumer Delinquency and Bankruptcy Behavior: An Empirical Analysis of Credit Card Data." Quarterly Review of Economics and Finance 43(2).

Bennett, P., R. Peach, and S. Peristiani. 2001. "Structural Change in the Mortgage Market and the Propensity to Refinance." Journal of Money, Credit, and Banking 33: 955-975.

Carpenter, J. N., and A.W. Lynch. 1999. "Survivorship Bias and Attrition Effects in Measures of Performance Persistence.” Journal of Financial Economics 54: 337-374.

Deng, Y., J. Quigley, and R. Van Order. 2000. "Mortgage Termination, Heterogeneity and the Exercise of Mortgage Options.” Econometrica 68: 275-307.

Domovitz, I., and R. L. Sartain. 1999. "Determinants of the Consumer Bankruptcy Decision." Journal of Finance 54: 403-420.

Elul, R., and N. Subramanian. 2002. "Forum Shopping and Personal Bankruptcy." Journal of Financial Services Research 21: 233-255.

Fay, S., E. Hurst, and M. J. White. 2002. "The Household Bankruptcy Decision." American Economic Review 92: 706-718.

Gropp, P. J., K. Scholz, and M. J. White. 1997. "Personal Bankruptcy and Credit Supply and Demand." Quarterly Journal of Economics 112: 217-251.

Grieb, T., C. Hegji, and S. T. Jones. 2001. "Macroeconomic Factors, Consumer Behavior, and Bankcard Default Rates.” Journal of Economics and Finance 25: 316-327.

Gross, D. B., and N. S. Souleles. 2002. "An Empirical Analysis of Personal Bankruptcy and Delinquency.” Review of Financial Studies 15: 319-347.

Hendershott, P., and W. Schultz. 1993. "Equity and Nonequity Determinants of FHA SingleFamily Mortgage Foreclosures in the 1980s." Journal of the American Real Estate and Urban Economics Association 21: 405-430. 
Livshits, I., J. MacGee, and M. Tertilt. 2001. Consumer Bankruptcy: A Fresh Start. Working Paper \#617, Research Department, Federal Reserve Bank of Minneapolis.

Repetto, A. 1998. Personal Bankruptcy and Individual Wealth Accumulation. Ph.D. Thesis, MIT.

Sullivan, T., E. Warren, and J. Westbrook. 2000. The Fragile Middle Class: Americans in Debt. New Haven: Yale University Press.

\section{Appendix}

PRoportional HaZard Model Estimates of ALl the VARIABLES FOR THE REGRESSION ROW NUMBER 1 FROM TABLE 1

\begin{tabular}{lrrr}
\hline Variables & Parameter & Chi-Square & T-Stat \\
\hline External Score (t-3) & -0.003434 & 13,584 & -143.00 \\
Internal Score (t-3) & -0.00344 & 345 & -14.54 \\
Account Balance (t-3) & 0.0002345 & 11,532 & 133.04 \\
Line Amount (t-3) & -0.000565 & 3,234 & -54.43 \\
State Average Income (t-3) & -0.000004 & 3.34 & 1.34 \\
State No Medical Coverage (t-3) & 0.056983 & 23.34 & 5.34 \\
County Unemployment Rate (t-3) & 0.002133 & 21.23 & 5.32 \\
Time Fixed Effects & Yes & & \\
State Fixed Effects & Yes & & \\
Number of Observations/Number of Accounts & 7.129 Million & 203,130 & \\
\hline
\end{tabular}

